\title{
Adoption and Impact of Conservation Agriculture on Smallholder Farmers' Crop Productivity and Income in Luapula Province, Zambia
}

\author{
Stanford Nkhoma ${ }^{1}$, Thomson Kalinda ${ }^{1} \&$ Elias Kuntashula ${ }^{1}$ \\ ${ }^{1}$ Department of Agricultural Economics \& Extension, University of Zambia, Lusaka, Zambia \\ Correspondence: Elias Kuntashula, Department of Agricultural Economics \& Extension, University of Zambia, \\ Lusaka, Zambia. Tel: 260-9-7774-8335. E-mail: ekuntashula@unza.zm
}

Received: June 15, 2017

doi:10.5539/jas.v9n9p168
Accepted: July 23, $2017 \quad$ Online Published: August 15, 2017

URL: https://doi.org/10.5539/jas.v9n9p168

\begin{abstract}
Despite efforts to systemically disseminate Conservation Agriculture (CA) technology in Luapula Province of Zambia, the adoption rate remains limited. Furthermore, no empirical evidence has been presented on the factors influencing adoption of the technology or the extent to which farmers' livelihood has been influenced due to uptake of the technology. This study therefore examined the adoption and impact of CA on crop productivity and income on farming households in the Province. Using the 2012 Rural Agricultural Livelihood Survey (RALS) data, the study employed a probit regression model to identify factors influencing adoption of CA among the smallholder farmers in the Province. The probit regression analysis showed that advice on CA and access to wetlands/dambos by households increased the probability to adopt CA. The study also adopted the Propensity Score Matching (PSM) approach to help match the adopters and non-adopters based on observable covariates in order to assess technology impact by providing consistent estimates of the Average Treatment Effect on the Treated (ATT). The results showed a small but insignificant positive impact of CA on crop productivity and income. This suggests that adoption of CA has the potential to generate an improvement in farming households' livelihood in Luapula Province, Zambia. Therefore, adoption of CA in Luapula Province should be explicitly encouraged. This can be further enhanced by increased access to quality extension services that incorporates promotion of CA practices among the smallholder farming households in the area.
\end{abstract}

Keywords: adoption, impact, conservation agriculture, probit model, propensity score matching

\section{Introduction}

In southern Africa, climate change is already having an adverse impact on food security especially in the countries with large rural populations dependent on rain fed agriculture (FAO, 2011) and Zambia is no exception. Conservation Agriculture (CA) has been identified as a priority technology to help arrest this situation and improve the productivity of most soils among smallholder farmers (CFU, 2007a; Arslan et al., 2013). The Conservation Farming Unit (CFU) of Zambia National Farmers Union (ZNFU) has defined CA as a farming practice that is anchored on three core principles: minimum mechanical soil disturbance, maintenance of permanent soil cover and diversified crop rotation including the use of legumes.

In Zambia, the emergency of CA dates back to the late 1980s and early 1990s when droughts and prolonged dry spells where experienced in many parts of the country (Haggblade \& Tembo, 2003). Coupled with some economic challenges experienced by most smallholder farmers, due to the Government's withdrawal of subsidies and subsequent introduction of a free market economy, a number of national and international institutions came on board to promote CA practices in Zambia (Haggblade \&Tembo, 2003). One prominent institution was the Co-operative League of the United States of America (CLUSA) which made the use of CA practices a pre-condition for accessing input credit among the smallholder farmers (Haggbade \& Tembo, 2003). The first project in Zambia on CA was the Soil Conservation and Fertility (SCAFE) project that started in the Eastern Province of Zambia (later expanded to Lusaka Province) and was funded by the Swedish International Development Agency (SIDA) (Baudron et al., 2007).

In the late 1999, GRZ through then Ministry of Agriculture and Co-operatives (MACO), officially declared CA and related technologies as a priority for promotion by both MACO and the various partner institutions such as the CFU of the ZNFU, Golden Valley Agricultural Research Trust (GART), Agricultural Support Programme (ASP), World Agro-forestry Centre (ICRAF) (GART, 2001). The main objective was to ensure that there was 
increased access to extension services that incorporated CA practices among the small and medium scale farmers. By the mid-1990s CA practices were prominent among some farmers especially the use of hand hoe basins (Haggblade \& Tembo, 2003). Since then, CFU has been at the center of CA promotion in Zambia especially in Agro-Ecological Region (AER) I and II due to these regions' vulnerability to the effect of climate change (Kabwe \& Donovan, 2005). Zambia is divided into three main Agro-Ecological Regions (AERs) according to annual rainfall which are; Agro-ecological region I with average annual rainfall of $800 \mathrm{~mm}$, Agro-ecological region II with annual rainfall of $950 \mathrm{~mm}$ and Agro-ecological region III with average rainfall of 1,200 $\mathrm{mm}$ or above. AER II is further sub-divided in to IIa and IIb based on differences in soil type. CA has been actively promoted in seven of the ten provinces of Zambia since the 1980s (Arslan et al., 2013). By 2011, CFU had reported that about 170,000 smallholder farmers in 17 districts of Zambia were practicing CA (Baudron et al., 2007).

In Luapula Province of Zambia, which is one of ten provinces of Zambia and is located in the northern part of the country in AERIII, CA has been promoted by some development programmes and organizations such as Programme for Luapula Agriculture and Rural Development (PLARD) and the Food and Agricultural Organization (FAO) in collaboration with the Ministry of Agriculture (MoA) in order to address the problem of low crop productivity due to declining soil fertility. Despite efforts to systematically disseminate CA technology in the province, the adoption rate remains limited. Most of the farmers have continued using methods and techniques of traditional agricultural production which have perpetuated the problem of low crop productivity (Mute, 2008). Furthermore, no empirical evidence has been presented on the factors influencing the adoption of the technology or the extent to which farmers' livelihood has been influenced in the Province (Haggblade \& Tembo, 2003). Most studies have concentrated in agro-ecological region I and II because of these areas' vulnerability to adverse events such as droughts and prolonged dry spells (Kabwe \& Donovan, 2005). Few CA adoption and impact studies if any, have been conducted in agro-ecological region III. This study therefore was an attempt to investigate and analyze the factors affecting adoption of CA and its impact on crop productivity and income among small holder farmers in Luapula Province of Zambia so as to bridge this information gap. Therefore, proper analysis of the findings of this study are important for the design and implementation of policies and strategies that aim to create sustainable livelihoods among smallholder farmers in Luapula Province in particular and Zambia in general.

\subsection{Literature Review}

A number of empirical studies have been undertaken to analyze factors affecting CA adoption in Zambia (for example: Haggblade \& Tembo, 2003; Chomba, 2004; Baudron et al., 2007; Haggblade, Kabwe, \& Plerphoples, 2011; Nyanga, 2012; Arslan et al., 2013; Ng'ombe et al., 2014). Arslan et al. (2013) argues that most of these studies have not effectively captured the multiple factors that affect farmers' decision to adopt the technology. A review of some of the studies has shown that there are three primary constraints to adoption of CA among smallholder farmers in Zambia. These constraints are the use of crop residues for other purposes (such as stock feed), labour constraints and limited potential to grow cover crops during dry season (Umar et al., 2011). Many authors have argued that labour constraint is the major constraint to CA adoption in Zambia (Haggblade \& Tembo, 2003; Baudron et al., 2007; Umar et al., 2011) which manifests itself during land preparation and weeding. Baudron et al. (2007) and Mazvimavi (2011) observe that labour constraint tends to be one of the main prohibiting factors because many smallholder farming households cannot afford to pay daily wages which are usually high during peak times such as during land preparation and weeding.

Arslan et al. (2013) found a very strong and robust relationship between the district level variation in historical rainfall during the growing season and adaptation as well as the intensity of adoption of the CA practices. The study found no evidence for the role of labour constraint, age, or education in the adoption decision. Ng'ombe et al. (2014) found that age, marital status, access to loans and labour availability positively influenced the likelihood to adopt CA and that off-farm income, access to extension services and ownership of livestock had a negative influence on the likelihood to adopt CA in Zambia. AER in which a farmer is located and distances to vehicular road were found to be statistically significant to affecting adoption of CA in Zambia.

Nyanga et al. (2011) found a positive correlation between perception of increased climate change variability and the use of CA, but no correlation between attitudes towards climate change itself and CA among smallholder farmers in Zambia. They observed that farmers are using minimum tillage/planting basins as a strategy to mitigate the risk of rainfall variability. The reach of extension services in a village (i.e. the proportion of households that receive information in minimum tillage) was found to positively affect both adoption and the intensity of adoption. 
In another study in Zambia, Nyanga (2012) observed that training in CA increased the likelihood to adopt the technology and that it also had a positive influence on area under CA. However experience in terms of age of household head indicated a significant negative influence on CA adoption. This means that older farmers are less likely to adopt CA than the younger ones. This is inconsistent with studies by Jera and Ajayi (2008) and Ng'ombe et al. (2014) who found a positive correlation between age and CA adoption. Ownership of labour saving equipment such as rippers coupled with the prestige associated with owning such implements increased the likelihood of adopting CA. This result is consistent with studies such as Chomba (2004), Umar et al. (2010), Mavunganidze et al. (2013), and Lugandu, (2013) who found that ownership of productive assets increases the likelihood of adopting a given technology. As regards gender, the study revealed that men and women were more likely to adopt CA by ripping and CA basins respectively from among the various variants of CA being promoted by Conservation Agriculture Project (CAP). The study further revealed that different farmer categories adopted different variants of CA and that this increased the likelihood of adopting the technology. For instance, farmers who could not afford Animal Draught Power (ADP) for ripping had an opportunity to practice CA using basins. This is mainly the case for most women farmers because women often lack access to productive resources (Long, 2006). Some indicators of wealth, human capital and financial capacity such as ownership of cattle, level of education of household head and access to credit showed a negative correlation with adoption of CA respectively. This is contrary to some studies such as Nkala (2012), Arslan et al. (2013), and Mlenga et al. (2015). Other institutional factors such as access to extension services and membership to agricultural organizations indicated an increase in the likelihood to adopt CA.

Baudron et al. (2007) observed that most of the cultural practices were in conflict with the CA principles in Southern Province of Zambia. Most of the farmers are traditionally pastoralists and cattle are mostly devoted to plowing large portions of land hence defeating the principle of minimum soil disturbance. The crop residues are also collected and fed to the animals or animals are allowed to graze freely on crop residues also defeating the principle of maintaining a permanent soil cover. Growing of cover crops is a challenge because replacing a legume such as beans used traditionally in intercropping by a cover crop (such as Canavalia or Mucuna) is not preferred especially if the primary objective of the household is food security. Therefore, weed control remains a challenge among most of the smallholder farmers because it requires hoeing numerous times or using herbicides, which is costly for the farmers. Umar et al. (2011) had similar findings in the study aimed at examining agronomic practices of smallholder CA farmers in Zambia's AER I and IIb. Out of the 129 households interviewed, only one household practiced CA on all cultivated fields. Most of the households were practicing both CA and conventional farming on different plots. The reasons ranged from tradition and culture to socio-economic. For instance, crop residue retention was difficult to practice because livestock was culturally allowed to graze on free range basis and fencing off of fields is traditionally unacceptable in most communities besides being expensive. Crop rotation was found to be difficult to practice as recommended because most households did not want to grow legumes which did not have a market. They would rather have the legumes intercropped with crops like maize which had a market and can also be used for food security purposes.

According to Becerril and Abdulai (2010), adoption of technology involves use of a bundle of innovations rather than just a single element of productivity enhancing factors. Most studies on CA adoption in SSA (Zambia inclusive) such as Mazvimavi and Twomlow (2009), Kassie et al. (2009), and Arslan et al. (2013) have shown that most small scale farmers hardly adopt the whole package of CA: minimum tillage, permanent soil cover and diversified crop rotation. The studies have shown that small scale farmers tend to adopt only some of the components-usually the minimum tillage and herbicides use in the initial stages. Kassie et al. (2009) argue that if farmers adopt partially, rather than the whole package, then the productivity improving effect of each of the components may not be realized. However in order to realize the full benefits of CA, the use of full package is advised (FAO, 2001; Ito et al., 2007).

\section{Methodology}

\subsection{Data and Data Sources}

This study used primary data derived from a household survey conducted in 2012 by Indaba Agricultural Policy Research Institute (IAPRI) in conjunction with the Ministry of Agriculture and Livestock (MAL) and Central Statistical Office (CSO. This survey known as Rural Agricultural Livelihood Survey (RALS)-2012 was conducted country wide and was aimed at studying options to improve crop production and marketing, and food consumption among small holder farmers in Zambia. A total of 8,500 smallholder farmer households were covered in the survey but this study only focuses on the data captured from 840 farming households in all the districts of Luapula Province. The data from the survey was suitable for this kind of study since it included variables related to CA adoption, crop productivity and generally, farmer livelihoods. 


\subsection{Types of Data}

According to Adesina and Zinah (1993), there are essentially three paradigms commonly used for explaining adoption behaviour and determinants of technology adoption. These are the innovation diffusion model, the adopters' perception model and the economic constraints model. This study only considered the innovation diffusion and economic constraints models in selecting the covariates because the RALS-2012 data set used in this study did not contain variables related to farmer perceptions. Furthermore, the covariates considered in this study were based on the regularity with which a variable was cited in the literature. A number of past research have documented factors that affect farmers' decision to adopt various soil conservation technologies (Kuntanshula et al., 2002; Gladwin et al., 2002; Ajayi et al., 2003; Keil et al., 2005; Jera \& Ajayi, 2008). Table 1 below indicates the covariates used in the probit model and their hypothesized relationships with the dependent variable are also defined.

Table 1. Definition of variables and a priori expectation

\begin{tabular}{|c|c|c|}
\hline Variable name & Description & $\begin{array}{l}\text { Expected effect on } \\
\text { CA adoption }\end{array}$ \\
\hline \multicolumn{3}{|l|}{ Dependent variables } \\
\hline Adoption of CA & \multicolumn{2}{|l|}{ If household adopted CA, $1=$ yes, 0 otherwise } \\
\hline Crop Productivity & \multicolumn{2}{|l|}{ Quantity of maize crop harvested over area cropped } \\
\hline Household income & \multicolumn{2}{|l|}{ Estimated household crop income per season (ZMK'000) } \\
\hline \multicolumn{3}{|l|}{ Explanatory variables } \\
\hline \multicolumn{3}{|l|}{ Demographic characteristics } \\
\hline Age & Age of household head (years) & $+/-$ \\
\hline Marital status & Marital status of household head (= 1 if married, 0 otherwise) & $+/-$ \\
\hline Adult equivalent & Number of household members (15-59 years) & + \\
\hline \multicolumn{3}{|l|}{ Socio-economic characteristics } \\
\hline Own livestock (Dummy) & If household owns livestock ( $=1$ if yes, 0 otherwise) & $+/-$ \\
\hline Own Radio set (Dummy) & Radio set dummy ( $=1$ if yes, 0 otherwise) & + \\
\hline Own Cellular (Dummy) & Cellular dummy (= 1 if yes, 0 otherwise) & + \\
\hline Own Borehole (Dummy) & Borehole dummy (= 1 if yes, 0 otherwise) & + \\
\hline Gross off farm income & Gross off-farm income (ZMK'000) & $+/-$ \\
\hline Distance to tarmac & Distance to a tarred road $(\mathrm{km})$ & $+/-$ \\
\hline Field wetland/dambo (Dummy) & Own wetland (= 1 if yes, 0 otherwise) & $+/-$ \\
\hline Area planted & Area planted (ha) & $+/-$ \\
\hline \multicolumn{3}{|l|}{ Institutional characteristics } \\
\hline Field tenure & Tenure of the field ( $=1$ if secure, 0 otherwise) & $+/-$ \\
\hline Advice in CA (Dummy) & Access to advice in CA ( $=1$ if yes & + \\
\hline Credit (Dummy) & Access to credit (= 1 if yes, 0 otherwise) & + \\
\hline Farmer group/coop.(Dummy) & Belongs to farmer group ( $=1$ if yes, 0 otherwise) & + \\
\hline Radio programme (Dummy) & Listens to radio program ( $=1$ if yes, 0 otherwise) & + \\
\hline Distance to agro-dealer & Distance to agricultural dealer $(\mathrm{km})$ & $+/-$ \\
\hline Distance to sale point & Distance to the selling point $(\mathrm{km})$ & $+/-$ \\
\hline
\end{tabular}

\subsubsection{Demographic Factors}

Age of the household head is used as a proxy for farming experience. However, the influence of age on adoption of CA has been mixed in most literature. Some studies have found that age had no influence of farmer's decision to adopt CA (Gbetibouo, 2009). On the other hand some studies have found that age is significantly and negatively related to farmer's decision to adopt CA (Adesina \& Baidu-Forson, 1995; Asiedu-Darko, 2014). In this study, therefore, the variable age is hypothesized a priori to have both a negative and positive influence on farmers' decision to adopt CA. Education level of the household head was used as a proxy for a farmer's ability to acquire and effectively use information. It is a measure of human capital development and enables an individual farmer to have access to information and make informed decisions about resource management (Asafu-Adjaye, 2008; Asiedu-Darko, 2014). In this study, the variable Education level of household head is 
hypothesized a priori to have a positive influence on a farmer's decision to adopt CA. Studies have also shown that over representation of men in programmes involving new innovations is linked with strong traditional and cultural practices that distinguish gender roles in agriculture mostly biased towards men (Nkala, 2012). Female headed households therefore may respond less favorably to new technology than male headed households because the traditional power structure and controls over household productive resources are less favorable to women (Jera \& Ajayi, 2008). Female headed households are more likely to face a bigger constraint in terms of land and other resources. This study therefore hypothesized a priori male headed households are more likely to adopt CA than those which are female headed. Conservation Agriculture is perceived to be a labour intensive technology such that families with a large number of members who are able to contribute to family labour are seen to be well off in terms of labour availability. This is so because most of the rural smallholder households depend on family labour in their day to day agriculture activities (Hassan \& Nchemachena, 2008). Large households will be able to provide the labour that might be required by new technology (Tadesse \& Belay, 2004; Gregory \& Sewando, 2013). It is therefore expected that households with large families are more likely to adopt CA and hence a positive relationship was hypothesized a priori in this study.

\subsubsection{Socio-Economic Factors}

Ownership of land and livestock were used as proxies for wealth endowment. Wealth enhances risk taking and the probability that a farmer will invest in new technology (Jera \& Ajayi, 2008). It is expected that households with a large number of animals can easily convert some of the livestock in to the much needed cash to invest in new technologies. At the same time, farmers with a bigger land holding will be more likely to set aside extra land to practice new technology (Jera \& Ajayi, 2008) and can also use it as collateral for accessing credit (Gregory \& Sewando, 2013). It is envisaged that assets tend to increase the ability of a farmer to adopt CA (Hassan \& Nhemachena, 2008). A priori, size of land holding and herd size is hypothesized to have a positive relation with the adoption decision of CA in this study. Off-farm income is one other important factor that directly influences farmers' decision to adopt CA. Knowler and Bradshaw (2007) noted that the adoption of agricultural technologies requires sufficient financial wellbeing, as such, it is expected that there would be a positive correlation between off-farm income and the decision to adopt CA. However, some studies such as Gebetibouo (2009) and Ng'ombe et al. (2014) found a negative correlation between off-farm income and the decision to adopt CA. A priori off-farm income is therefore both negatively and positively related to farmers' decision to adopt $\mathrm{CA}$.

\subsubsection{Institutional Factors}

Land tenure is an important institutional factor affecting agricultural technology utilization by smallholder farmers. It provides incentives for greater investment to enhance the productivity of the land. Nowak and Korsching (1983) argue that farmers who own land use a broader number of management strategies and adopt best practices earlier than farmers who rent. Since there is no guarantee that farmers who rent land will reap benefits of long term soil conservation, tenant farmers are expected to use management strategies that maximize short term production even if this compromises future soil fertility. It is therefore hypothesized a priori that secure land tenure has a positive relationship with the likelihood to adopt CA. Membership of the household head to a farmer group or cooperative is conceptualized to improve on an individual farmer's social capital development. According to Jera and Ajayi (2008), membership to a cooperative or commodity association increases access to productive resources such as seed, information and training. It is hypothesized $a$ priori that membership to a farmer group positively influences a farmer's decision to adopt CA. Access to advice in crop and livestock production is an important source of information on production practices. Extension education is found to be an important factor in motivating increased use of specific soil and water conservation practices (Bekele \& Drake, 2003). According to Hisali et al. (2011) and Deressa et al. (2009) access to extension education was found to be positively correlated to a farmer's decision to adopt technologies that mitigate the effects of climate change. Bryson et al. (2009) and Kassie et al. (2012), argue that access to extension education is not very important but concludes that what is important is the message included in the extension package. In this study it is hypothesized a priori that extension messages on CA practices have a positive influence on a farmer's decision to adopt a new technology. Access to credit is an important determinant enhancing the adoption of various technologies (Tembo et al., 2001; Nyanga, 2011). Access to credit has been found to enhance farmers' capability to improve their management practices in response to changing climate (Deressa et al., 2009; Bryson et al., 2011). This study therefore hypothesized a priori that access to credit has a positive influence on a farmer's decision to adopt CA.

Distance to both input and output markets plays an important role in a farmer's decision to adopt soil conservation practices. It is conceptualized that a readily available input and output market could influence the 
uptake of a technology (Mutuma, 2013). On the other hand, long distances to input and output markets are potentially a disincentive to engage in CA practices. This study therefore hypothesized a priori both a negative and positive relationship between distance to output and input market with the farmer's decision to adopt CA.

\subsection{Data Analysis}

\subsubsection{Empirical model specification}

Since the adoption of CA is dichotomous or binary dependent variable, with the option of either adoption or non-adoption, the probit regression model was applied as the most appropriate tool to investigate how each explanatory variable affects the probability of falling in to the treatment group (Caliendo \& Hujar, 2005). The model explores the demographic, socio-economic and institutional factors influencing the adoption of CA. For the purpose of this study, the adopter was defined as one who used at least one or more of the three core principles of CA: Minimum soil disturbance, permanent soil cover and diversified crop rotation. The results of the regression were therefore subjected to a binary coding, where by 1 represented practicing CA and 0 otherwise. The probit econometric model was presented as given below:

$$
\operatorname{Pr}\left(D_{i}=1 / x_{i}\right)=\Phi\left\{h\left(x_{i}\right)\right\}
$$

Where,

$\Phi$ : Denotes the normal cumulative distribution function; $h\left(x_{i}\right)$ : A starting specification that includes all covariates as linear; $D_{i}$ : Indicator of exposure to treatment (CA); $x_{i}$ : A vector that contains a set of covariates deemed to influence farmer decision to practice CA.

\subsubsection{Propensity Score Matching (PSM)}

The PSM method is a two stage process for estimating the Average Treatment on the Treated (ATT). Firstly, a probit econometric regression is performed by calculating household propensity to be in the CA group, that is, $p(x)$ (Equation 1), and then secondly uses the propensity scores obtained in the first stage to match the CA and non-CA farmers with similar values of Propensity scores (Equation 3) (Nkala, 2011). The main purpose for using matching was to find a group of treated individuals (adopters) similar to the control (non-adopters) in all relevant pre-treatment characteristics, where the only difference was that one group adopted the technology (CA) and the other did not. The PSM method compares the outcome of technology participants with those of matched non-participants, where matches are chosen on the basis of similarity in observed characteristics (propensity to participate). The propensity score is defined as the conditional probability of receiving the treatment given pre-treatment characteristics (Rosenbaum \& Rubin, 1983). Let $D_{i}$ denote a dummy variable equal to 1 if household adopted CA and 0 otherwise then the propensity score can be defined as

$$
P(X)=\operatorname{Pr}\left(D_{i}=1 / X\right)=E\left(D_{i} / X\right)
$$

Where,

$X$ is a vector of covariates that are postulated to affect adoption of CA (Rosenbaum \& Rubin, 1983) and $E($.$) is$ the expectations operator.

\subsubsection{Average Treatment on the Treated}

Using the propensity score estimates, $p(x)$, obtained from the probit econometric regression, the impact of CA was estimated by computing the Average Treatment on the Treated by specifically using the following model;

$$
A T T=E[y d=1 / y d=1, p(x)]-E[y d=0 / y d=0, p(x)]
$$

Where,

ATT: Average Treatment on the Treated; $y d=1 / y d=1$ : Reported changes in the outcomes of interest observed in the CA group; $y d=0 / y d=0$ : Reported changes in the outcomes of interest observed in non-CA group; $p(x)$ : Propensity Score (Conditional probability of being in the CA group given $x$ ).

The matching was done using the nearest neighbor matching estimator because it is more efficient than the other matching methods in that it only picks control units that are close in propensity score to the treated unit and therefore elimination of original observations is very minimal. The sensitivity of the estimated impact results (ATTs) is assessed by employing the Mantel and Haenszel (MH) test.

\section{Results and Discussion}

\subsection{Descriptive Statistics}

Table 2 and 3 below presents the summary of the descriptive statistics for the covariates of interest in this study. Table 2 indicates that the average age of the adopters was 46 years while for the non-adopters it was 45 years. 
The average age for the whole sample was 45 years. Adult equivalent was on average found to be approximately five members per household for both the adopters and non-adopters and for the whole sample. The highest level of education was secondary education for both the adopters and non-adopters representing $47.27 \%$ and $47.33 \%$ respectively. The highest level of education for the whole sample was found to be secondary education representing $42.20 \%$. The results indicate that there is no significant difference in the means of all the demographic characteristics between the adopters and non-adopters.

About $80 \%$ of the sampled households owned some form of livestock. About $81.50 \%$ and $79 \%$ of the adopters and non-adopters owned some form of livestock respectively. The results show that more of the adopters owned livestock as compared to the non-adopters but there is no significant difference in the two means. On average the gross off-farm income was 12,700 ZMW and 7,900 ZMW for adopters and non-adopters respectively. The results show that the adopters had a higher gross off-farm income than the non-adopters though the difference in the two means is insignificant. The average cropped land size was 0.67 ha and 0.69 ha for adopters and non-adopters respectively. The difference in the average cropped land is also insignificant. The average distance to the nearest agro-dealer was $16.7 \mathrm{~km}$ and $33.1 \mathrm{~km}$ for the adopters and non-adopters respectively. This indicates that the adopters were closer to the agro-dealers as compared to the non-adopters and the difference in the mean distance is highly significant. As for the nearest distance to output market, the average was $13 \mathrm{~km}$ and $12.7 \mathrm{~km}$ for the adopters and non-adopters respectively. The non-adopters have a slightly shorter distance to the output market as compared to the adopters though the difference is insignificant. About $4.40 \%$ of the adopters and $1.40 \%$ of the non-adopters had access to wetlands/dambos. This shows that more of the adopters utilized wetlands/dambos as compared to the non-adopters though the mean difference is insignificant.

The results in Table 2 indicate no significant difference in means of all institutional characteristics between the adopters and non-adopters apart from land tenure of field. The results indicate that $4.70 \%$ and $7.70 \%$ of adopters and non-adopters had land on title respectively. The results indicate that $47.30 \%$ and $42 \%$ of the adopters and non-adopters has received advice on CA respectively. About 3.60\% and 3.50\% of adopters and non-adopters were members of a farmer group or cooperative respectively. About $26.30 \%$ and $30.40 \%$ of the adopters and non-adopters had access to radio programmes respectively.

Table 2. Descriptive statistics of sample households

\begin{tabular}{|c|c|c|c|c|c|c|c|}
\hline \multirow{2}{*}{ Variable name } & \multicolumn{2}{|c|}{ Total sample } & \multicolumn{2}{|c|}{ CA Adopters } & \multicolumn{2}{|c|}{ CA Non-adopters } & \multirow{2}{*}{ - t-test } \\
\hline & Mean & Std. Deviation & Mean & Std. Deviation & Mean & Std. Deviation & \\
\hline \multicolumn{8}{|l|}{ Dependent variable } \\
\hline \multicolumn{8}{|l|}{ Adoption of CA (= 1 if yes) } \\
\hline \multicolumn{8}{|l|}{ Explanatory variables } \\
\hline \multicolumn{8}{|l|}{ Demographic characteristics } \\
\hline Age of household head (yrs) & 45.49 & 14.37 & 46.17 & 14.68 & 44.98 & 14.68 & 1.1820 \\
\hline Education of head (= 1 if attended) & 0.203 & 0.402 & 0.182 & 0.386 & 20.19 & 0.414 & 1.333 \\
\hline Adult equivalents (15-59 yrs) & 4.739 & 2.092 & 4.789 & 0.2099 & 4.701 & 2.089 & -0.5977 \\
\hline \multicolumn{8}{|l|}{ Socio-economic charactersitics } \\
\hline Own livestock (= 1 if yes) & 0.80 & 0.40 & 0.815 & 0.381 & 0.79 & 0.41 & -0.9416 \\
\hline Own cellular (= 1 if yes) & 0.467 & 0.499 & 0.468 & 0.500 & 0.468 & 0.499 & $12.907^{* * *}$ \\
\hline Own borehole $+(=$ if yes $)$ & 0.017 & 0.129 & 0.016 & 0.029 & 0.020 & 0.142 & 0.022 \\
\hline Own radio ( $=1$ if yes) & 0.595 & 0.491 & 0.580 & 0.494 & 0.607 & 0.489 & 0.7814 \\
\hline Gross off-farm income (ZMK'000) & 10.7 & 50.4 & 12.7 & 64.3 & 7.9 & 19.5 & 1.3749 \\
\hline Distance to agro-dealers $(\mathrm{km})$ & 21.550 & 36.255 & 16.969 & 33.129 & 24.936 & 38.083 & $3.1661^{* * *}$ \\
\hline Distance to tarmac $(\mathrm{km})$ & 27.782 & 29.660 & 29.221 & 29.473 & 25.834 & 29.840 & 1.6377 \\
\hline Distance to selling point $(\mathrm{km})$ & 12.893 & 45.124 & 13.049 & 43.716 & 12.778 & 46.183 & -0.0862 \\
\hline Field in wetland ( $=1$ if yes) & 0.027 & 1.163 & 0.044 & 0.207 & 0.014 & 0.119 & $-2.6705^{* * *}$ \\
\hline Area planted (ha) & 0.680 & 0.947 & 0.661 & 0.537 & 0.694 & 1.160 & 0,4941 \\
\hline \multicolumn{8}{|l|}{ Institutional characterstics } \\
\hline Land tenure of field ( $=1$ if yes) & 0.064 & 0.245 & 0.047 & 0.43 & 0.077 & 0.266 & $1.6941^{*}$ \\
\hline Advice in CA (= 1 if yes) & 0.443 & 0.497 & 0.473 & 0.499 & 0.420 & 0.494 & -1.5319 \\
\hline Credit from com. Bank (= 1 if yes) & 0.001 & 0.034 & 0 & 0 & 0.002 & 0.046 & 0.8396 \\
\hline Farmer group/coop. (= 1 if yes) & 0.036 & 0.186 & 0.036 & 0.188 & 0.035 & 0.184 & -0.0939 \\
\hline Radio programme (= 1 if yes) & 0.287 & 0.452 & 0.263 & 0.441 & 0.304 & 0.460 & 1.2993 \\
\hline
\end{tabular}

Source: Own computation. 
Table 3 below shows that out of the 359 CA adopters, 89 were using crop rotation, 40 were using CA basins, 2 were using ripping, 18 were using zero tillage, 205 were using planting on moulds (moulding) and 119 were retaining crop residue in their farming systems.

Table 3. Farmers who used specific practices as a percentage of CA adopters

\begin{tabular}{lll}
\hline Type of practice & Proportion of CA adopters $(\mathbf{n}=\mathbf{3 5 9})$ & Percentage proportion $(\mathbf{\%})$ \\
\hline Crop rotation & 89 & 24.7 \\
Planting in basins (CA basins) & 40 & 11.1 \\
Ripping & 2 & 0.5 \\
Zero tillage & 18 & 5.01 \\
Crop residue retention & 119 & 33.14 \\
Moulding & 205 & 57.1 \\
\hline
\end{tabular}

Note. The percentage is not adding to $100 \%$ because the same farmer can be using one or more of the practices.

Source: Own computation.

\subsection{Empirical Results}

\subsubsection{Probit Regression Results}

Table 4 below shows the probit regression results of the factors affecting adoption of CA among the small holder farmers in Luapula Province. The table reports the estimated coefficients, the z-values and standard errors of the probit regression model. The results give an indication of the likelihood of farming households to adopt CA in terms of the demographic, socio-economic and institutional determinants. The table indicates that only five covariates were significant in the regression namely; Secondary education of household head, access to relevant radio programmes, distance to agro-dealers, access to wetlands/dambos and access to advice in CA.

Table 4. Probit estimates for adoption of conservation agriculture

\begin{tabular}{|c|c|c|c|}
\hline Variable & Coefficient & Std.Error & $\mathbf{P}>|\mathbf{z}|$ \\
\hline \multicolumn{4}{|l|}{ Demographic factors } \\
\hline Adult equivalent (15-59 yrs) & 0.0155 & 0.0241 & 0.519 \\
\hline Education (yrs) & $-0.260^{*}$ & 0.247 & 0.068 \\
\hline Age & -0.0520 & 0,114 & 0.087 \\
\hline \multicolumn{4}{|l|}{ Socio-economic factors } \\
\hline Distance to sale $(\mathrm{km})$ & $-9.27 e-05$ & $9.77 \mathrm{e}-04$ & 0.924 \\
\hline Distance to agro-dealer (km) & $-0.0361^{* * *}$ & 1.105 & 0.007 \\
\hline Area planted (Ha) & -0.0124 & 0.056 & 0.820 \\
\hline Distance to tarmac $(\mathrm{km})$ & -0.00151 & 0.00133 & 0.345 \\
\hline Income off-farm (ZMK'000) & $-2.48 \mathrm{e}-09$ & 0.00160 & 0.263 \\
\hline Field wetland (= 1 If yes) & $0.719^{* * *}$ & $2.21 \mathrm{e}-09$ & 0.012 \\
\hline Own livestock (= 1 If yes) & 0.0166 & 0.115 & 0.314 \\
\hline Own cellular (= 1 If yes) & 0.0158 & 0.114 & 0.878 \\
\hline Own borehole (= 1 If yes) & 0.0400 & 0.150 & 0.908 \\
\hline Own Radio (= 1 If yes) & 0.138 & 0.102 & 0.357 \\
\hline \multicolumn{4}{|l|}{ Institutional factors } \\
\hline Advice in CA (= 1 If yes) & $0.166^{*}$ & 0.347 & 0.080 \\
\hline Radio Programme (= 1 If yes) & $-0.181^{*}$ & 0.244 & 0.087 \\
\hline Infor farmer group/coop (= 1 If yes) & -0.145 & 0.0231 & 0.555 \\
\hline Field tenure (= 1 If yes) & -0.314 & 0.286 & 0.115 \\
\hline Credit from com. Bank (= 1 If yes) & -0.129 & 0.939 & 0.170 \\
\hline Constant & 0.0769 & 0.227 & 0.734 \\
\hline Observations & 840 & & \\
\hline
\end{tabular}

Note. ${ }^{* * *} \mathrm{P}<0.01,{ }^{* *} \mathrm{p}<0.05,{ }^{*} \mathrm{p}<0.1$.

Source: Model output. 
The results show that the education level of the household head is negatively correlated with the decision to adopt CA. The result indicates a 0.260 reduction in probability to adopt CA at $10 \%$ level of significance if the household head attained formal education as compared to those who did not. Generally education is expected to positively influence the adoption decision (Gould et al., 1989; Mupangwa et al., 2012) despite the fact that there are negative influences reported. For instance Ralm and Huffman (1984), Knowler and Bradshaw (2007) found a negative relationship between level of education and adoption of CA. The plausible explanation is that formal education system as implemented in Zambia, and generally in many other African countries, has limited relevance for practical implementation of agricultural practices and could even be conducive to practices that are against practical farming. Wondwosen et al. (2011) had similar results in the study on adoption of CA and its impact on labour and land productivity in central Ethiopia.

Advice in CA tends to positively influence the decision to adopt CA and increases the probability to adopt the technology by 0.166 at $10 \%$ level of significance for farmers who had access to extension services as compared to those who did not. This is consistent with findings by Gould et al. (1989) and Stonehouse (1991) who emphasize that awareness of soil problems on the part of farm operators is an obvious pre-requisite to adoption. Extension services make farmers aware of the importance of CA and how to apply it as well as the benefits associated with the technology (Logan, 1990; Tsegave et al., 2011). Extension services are known to reduce the uncertainty associated with adopting complex technologies such as CA (Pannell et al., 2006; Knowler \& Bradshaw, 2007).

Wetlands, known locally as dambos, in southern Africa are widely used for vegetable production. Declining soil fertility and dry spells has resulted in increased utilization of the dambos/wetlands for all year crop production in sub-Saharan Africa (Ellis-Jones \& Mudhara, 1995; MEA, 2005). The probit estimate results in this study therefore indicate a 0.719 increase in probability to adopt CA at $1 \%$ significance level if the household had access to wetlands/dambos as compared to those who did not have access.

Distance to agro-dealers showed a negative relationship with farmers' decision to adopt CA. The results are indicating a 0.0361 decrease in probability to adopt CA at $1 \%$ significance level. This result is consistent with the findings by Ngoma (2012), and Hassan and Nhemachena (2008). They argue that on average the further away the input markets the more costly it is for farmers and hence reduced profits. The plausible explanation in this study can be that there are very few agro-dealers in most districts of Luapula Province. Farmers have to travel hundreds of kilometers to Mansa district (The Provincial capital) in order to access the services from agro-dealers.

Access to relevant agriculture radio programmes tends to negatively influence farmer involvement in CA activities. The results indicate a 0.181 reduction in probability to adopt CA at $10 \%$ significance level if a farmer had access to radio programmes as compared to those who did not have access. This is inconsistent with a study by Chapman et al. (2003) on rural radio in agriculture extension in northern Ghana who found that access and listening to rural radio had a positive influence on farmers' understanding of soil and water conservation practices. The plausible explanation of the negative relationship in this study can be attributed to fewer farmers owning radio sets (only $15.50 \%$ ) and also unavailability of clear rural radio signals in most remote parts of Luapula Province. For instance, at the time of the study, the province had only two community radio stations (Radio Yageni and Radio Luapula) with very few agriculture related programmes broadcast and have radii limited to only parts of Mansa and Nchelenge districts respectively.

Ownership of livestock, cellular phone, and borehole were used as proxies for wealth endowment and the results indicate a positive relationship with the decision to adopt CA. The results show an increase in probability by 0.0166 if a farmer owned livestock as compared to one who did not. The results also indicate an increase in probability to adopt CA by 0.0158 and 0.0400 if a farmer owned a cellular phone and borehole respectively as compared to one who did not. This is consistent with studies by Wondwosen (2011), Nyanga (2011), Nkala et al. (2012), and Ngoma (2012) who found a positive relationship between wealth and decision to adopt new technology.

\subsubsection{Treatment Effects from the Propensity Score Matching Results}

The ATT was estimated to assess the impact of CA on crop productivity and income. The ATT gives the mean difference between the observed crop productivity and incomes among the adopters and non-adopters. The analysis was based on estimated propensity scores from the probit regression results and generated samples of matched CA and non-CA groups using the nearest neighbour matching method. The common support condition was satisfied in this study as there was an overlap in the distribution of the propensity scores of both the treated and the non-treated sub-groups. Table 5 below indicates that out of a total of 840 subjects matched, a total of 830 
subjects were matched with in the region of common support and that 349 were in the CA sub group whilst 481 were in the non-CA sub group. The remaining 10 were off common support and hence discarded.

Table 5. Distribution of observations within region of common support

\begin{tabular}{llll}
\hline & Off common support & Within common support & Total \\
\hline Non-CA & 0 & 481 & 481 \\
CA & 10 & 349 & 359 \\
\hline Total & $\mathbf{1 0}$ & $\mathbf{8 3 0}$ & $\mathbf{8 4 0}$ \\
\hline
\end{tabular}

Table 6 below shows the results of the PSM technique. It indicates the mean difference between the observed crop productivity and income among the adopters and non-adopters, the ATT. The method uses estimated propensity scores from probit regression to generate samples of matched CA and non-CA groups using nearest neighbor matching method. Only observations within region of common support are used. In this case only 349 CA observations are indicated whose matches where obtained.

Table 6. Average treatment effect from nearest neighbour propensity score matching

\begin{tabular}{|c|c|c|}
\hline & \multicolumn{2}{|c|}{ Nearest Neighbour } \\
\hline & Crop Productivity (log) & Income $(\log )$ \\
\hline CA farmers $(\mathrm{N})$ & 357 & 359 \\
\hline Non CA farmers $(\mathrm{N})$ & 219 & 481 \\
\hline ATT & 0.062 & 0.029 \\
\hline Std.Error & 0.098 & 0.097 \\
\hline $\mathrm{T}$ & 0.358 & 0.0632 \\
\hline CA farmers & 349 & 349 \\
\hline Non CA farmers & 481 & 481 \\
\hline Total & 830 & 830 \\
\hline
\end{tabular}

Source: Own psmatch results.

The results in the table indicate that CA is positively correlated with crop productivity and income as estimates from the nearest neighbor matching algorithm show. The ATTs in the table indicate that on average CA increases crop productivity by $6.20 \%$ and household income by $2.90 \%$. The results are consistent with findings of other studies such as Nkala et al. (2012) who found a positive correlation between CA and crop productivity and income in his study on the impact of CA on farmer livelihood in central Mozambique. Awotide et al. (2012) equally found a positive impact of adoption of improved technology on sustainable productivity and farmers' welfare in Nigeria. Adebayo and Olagunju (2015) in there study in Nigeria also conclude that agricultural innovations such as CA have positive impact on farmers' livelihood. Baudron et al. (2007), in a case study in Southern Province of Zambia, observed that individual CA components (minimum tillage, permanent soil cover and diversified rotation) have specific effects in terms of improving soil fertility and hence productivity. Umar et al. (2010) contends that CA, as opposed to conventional farming, can yield positive results in terms of productivity in Zambia if properly implemented. Arslan et al. (2013) also observes that adoption of CA tend to decrease yield variability in Zambia.

\section{Conclusion and Recommendation}

The findings of the study suggest that the probability of a farmer adopting CA is increased if the household head received advice on CA because they will have a better understanding of the technology and will have reduced uncertainty as regards the technology. Access to wetlands/dambos tends to increase the probability of a farmer adopting CA. It is generally observed that many farming communities tend to embark on wetland/dambo utilization activities as a coping strategy where uplands are dominated by poor and degraded soils. Therefore farmers are more likely to take up soil improvement practices because wetlands/dambos will provide alternative land for crop production there by paving way for improving the fertility of the depleted upland soils by means of CA. Education status of household head, distance to agro-dealers and access to agriculture radio programmes were found to decrease the probability of a farmer adopting CA. The plausible explanation is that advancement 
in formal education tends to bring about specialization in technical skills that make farming, including CA, less attractive. The longer the distance to agro-dealers the less likely a farmer will adopt CA because of increased transaction costs. Lack of access to media will limit the chances of getting information on soil conservation practices such as CA and hence decreasing the probability of adopting the technology. Limited access to relevant agricultural information from the radio broadcasts have probably not had the desired impact of influencing farmers to adopt $\mathrm{CA}$ as expected.

The findings of the study show that adoption of CA improves the level of crop productivity and income. This implies that adoption of CA has the potential to improve the livelihoods among the smallholder farmers in Luapula Province. However, the small impact can be attributed to the fact that farmers were only partially adopting the three core principles of the technology. For CA to yield maximum benefits, all the three core principles should simultaneously be incorporated in the farming system (Derpsch, 2001; Kassama et al., 2010; Erestein et al., 2011). One important recommendation is that Extension service provision should be scaled up by strengthening partnership and collaboration between Ministry of Agriculture (MoA) and other institutions such as ZNFU, in order to create synergies and offer opportunities to further enhance adoption of CA. MoA should also increase on the delivery of radio listenership among farmers by continuing to promote Radio Farm Fora even on community radio stations. This will improve farmer access to relevant agricultural information on CA through radio broadcast.

\section{References}

Adebayo, O., \& Olagunju, K. (2015). Impact of agricultural innovation on improved livelihood and productivity outcomes among smallholder farmers in rural Nigeria. Retrieved from http://web2.msm.nl/RePEc/ msm/wpaper/MSM-WP2015-07.pdf

Adesina, A. A., \& Zinnah, M. M. (1993). Technology Characteristics. Farmers' Perceptions and Adoption Decision: A Tobit Model Application in Sierra Leone. Agricultural Economics, 9, 297-311. https://doi.org/10.1016/0169-5150(93)90019-9

Arslan, A., McCarthy, N., Liper, L., Arsfaw, S., \& Cattaneo, A. (2013). Adoption and Intensity of Adoption of Conservation Framing Practices in Zambia. ESA Working Paper No. 13-01. Retrieved from http://www.fao.org/3/a-aq288e.pdf

Awotide, B. A., Diagne, A., \& Omonona, B. T. (2012). Impact of improved agricultural technology adoption on sustainable rice productivity and rural farmers'welfare in Nigeria: A Local Average Treatment Effect (LATE) technique. Paper presented at the African Economic Conference, Oct. 30-Nov. 2.

Baudron, F., Mwanza, M. H., Triomphe, B., \& Bwalya, M. (2007). Conservation Agriculture in Zambia: A case study of southern province. African Conservation Tillage Network. Retrieved from http://www.fao.org/ ag/ca/doc/zambia_casestudy.pdf

Becerril, J., \& Abdulai, A. (2010). The impact of improved maize varieties on poverty in Mexico: A propensity score matching approach. World Development, 38(7), 1024-1035. https://doi.org/10.1016/j.worlddev. 2009.11.017

Bekele, W. J., \& Drake, L. (2003). Soil and water conservation behavior of Subsistence farmers in the Eastern Highlands of Ethiopia: A case study of the Hunde-Lafto area. Journal of Ecological Economics, 46, 437-451. https://doi.org/10.1016/S0921-8009(03)00166-6

Caliendo, M., \& Hujer, R. (2005). The Micro Econometric Estimation of Treatment Effects: An Overview (Vol. 90, No. 1, pp. 199-215). Retrieved from http://ftp.iza.org/dp1653.pdf

CFU (Conservation Farming Unit). (2007a). Conservation Farming and Conservation Agriculture Hand book for Hoe Farmers in Agro-Ecological Region I and IIa, ZNFU, CFU, Lusaka. Retrieved from http://www.fsnnetwork.org/sites/default/files/conservation_farming_handbook.pdf

Chapman, R., \& Tripp, R. (2004). Background Paper on Rural Livelihoods Diversity and Agriculture. Paper prepared for the 2004 agREN Electronic Conference on Implications of Rural Livelihood Diversity for pro-poor Agriculture Initiatives. Retrieved from file://C:/Users/HI/AppData/Local/Temp/Background_ Paper_on_Rural_Livelihood_Diversity_an.pdf

Chiputwa, B., Langyintuo, S. A., \& Wall, P. (2011). Adoption of conservation agriculture technologies by smallholder farmers in the Shamva district of Zimbabwe: A Tobit application. Southern Agricultural Economics Association, Texas, USA. Retrieved from http://ageconsearch.umn.edu/record/98851/files/ Chiputwa_etal_SAEA_Paper.pdf 
Chomba, N. G. (2004). Factors Affecting Smallholder Farmers' Adoption of Soil and Water Conservation Practices in Zambia. Master of Science in Agricultural Economics Thesis, Michigan State University. Retrieved from http://fsg.afre.msu.edu/zambia/chomba_thesis_updated_version.pdf

Derpsch, R. (2001). Frontiers of Conservation Tillage and advances in Conservation Practices. Southern America (p. 76). Retrieved http://tucson.ars.ag.gov/isco/isco10/SustainingTheGlobalFarm/K008-Derpsch.pdf

Erestein, O. (2003). Smallholder conservation farming in the tropics and sub-tropics: A guide to development and dissemination of mulching with crop residues and cover crops. Agriculture, Ecosystems and Environment, 100, 17-37. https://doi.org/10.1016/S0167-8809(03)00150-6

FAO. (2001). Economics of Conservation Agriculture. Retrieved from http://www.fao.org/docrep/004/y2781e/ y2781e00.htm

FAO. (2011). Save and grow: A policy maker's guide to sustainable intensification of smallholder crop production. Rome. Retrieved from http://www.fao.org/3/a-i2215e.pdf

GART. (2001). Golden Valley Agriculture Research Trust: 2000 Year Book. GART, Lusaka.

Gbetibouo, G. A. (2009). Understanding farmers' perception and adaptations to climate change and variability: The case of Limpopo basin, South Africa. IFPRI Discussion Paper No. 849. Washington DC, IFPRI. Retrieved http://www.fao.org/fileadmin/user_upload/rome2007/docs/ifpri_limpopo_dp00849.pdf

Giller, K. E., Witter, E., Corbeels, M., \& Tittonell, P. (2009). Conservation agriculture and smallholder farming in Africa: The Heretics' view. Field crops Research, 114, 23-34. https://doi.org/10.1016/j.fcr.2009.06.017

Gladwin, C. H., Peterson, J. S., Phiri, D., \& Uttaro, R. (2002). Agro-forestry adoption decision, structural adjustment and gender in Africa. In C. B. Barrett, F. Place, \& A. Aboud (Eds.), Natural resource management in African agriculture: Understanding and improving current practices (pp. 115-128). Wallingford UK: CAB International. https://doi.org/10.1079/9780851995847.0115

Gould, B. W., Saupe, W., \& Klemme, R. M. (1989). Conservation tillage: The role of operator characteristics and the perception of soil erosion. Land Economics, 65, 167-182. https://doi.org/10.2307/3146791

Gregory T., \& Sewando, P. (2013). Determinants of the probability of adopting Quality Protein Maize (QPM) technology in Tanzania: A logistic regression analysis. International Journal of Development and Sustainability, 2(2), in press. Retrieved from https://isdsnet.com/ijds-v2n2-21.pdf

Haggblade, S., \& Tembo, G. (2003). Early Evidence on Conservation Farming in Zambia. EPTD Discussion Paper No. 108. Washington DC: International Food Policy Research Institute. Retrieved from http://hdl.handle.net/10919/68475

Haggblade, S., Kabwe, S., \& Plerphoples, C. (2011). Productivity impact of conservation farming on smallholder cotton farmers in Zambia. FSRP Working Paper No. 47. Lusaka, Zambia: Food Security Research Project. Retrieved from https://pdfs.semanticscholar.org/7394/ee509a63e22e8c98c2ddfac9f4682b713b83.pdf

Hobbs, P. R. (2007). Conservation agriculture: What is it and why is it important for future sustainable food production. Journal of Agriculture Science, 145(2), 127-137. https://doi.org/10.1017/S0021859607006892

Hobbs, P. R., Sayre, K., \& Gupta, R. (2008). The Role of Conservation Agriculture in Sustainable Agriculture. Philosophical Trans. R Soc. Land B Biol. Sci., 353(1491), 543-555. https://doi.org/10.1098/rstb.2007.2169

Ito, M., Matsumoto, T., \& Quinones, M. (2007). Conservation Tillage in Sub-Saharan Africa: The Experience of Sasakawa Global 2000. Crop Protection, 26, 417-423. https://doi.org/10.1016/j.cropro.2006.06.017

Jera, R., \& Ajayi, O. C. (2008). Logistic modeling of smallholder livestock farmers' adoption of tree-based fodder technology in Zimbabwe. Agrekon Journal, 47(3), 379-392. https://doi.org/10.1080/03031853. 2008.9523806

Kabwe, S., \& Donovan, C. (2005). Sustainable use of conservation farming practices among small and medium scale farmers in Zambia. Food Security Research Project/Michigan State University, USA.

Kassam, A., Fredrich, J., Shaxson, F., \& Pretty, J. (2009). The spread of conservation agriculture, sustainability and uptake. International Journal of Agricultural Sustainability, 7(4). https://doi.org/10.3763/ijas. 2009.0477

Kassie, M., Shiferaw, B., \& Muricho, G. (2010). Adoption and impact of improved groundnuts varieties on rural poverty: Evidence from rural Uganda. Discussion Paper No. 10. Retrieved from http://fsg.afre.msu.edu/ zambia/WCCA_CF_adoption_paper_Oct_2005.pdf 
Keil, A., Zeller, M., \& Franzel, S. (2005). Improved tree fallows in smallholder maize production in Zambia: Do initial planters adopt the technology? Agroforestry Systems, 64, 225-236. https://oi.org/10.1007/s10457004-2410-0

Knowler, D., \& Bradshaw, B. (2007). Farmers' Adoption of Conservation Agriculture: A Review and Synthesis of Recent Research. Food Policy Research, 32, 25-48. https://doi.org/10.1016/j.foodpol.2006.01.003

Kuntashula, E., Ajayi, O. C., Phiri, D., Mafongoya, P., \& Franzel, S. (2002). Factors influencing farmers' decision to plant improved fallows: A study of four villages in Eastern Province of Zambia. In F. Kwesiga, E. Ayuk \& A. Agumya (Eds.), Proceedings of the $14^{\text {th }}$ South African Regional Review and planning workshop, September 3-7, Harare, Zimbabwe (pp. 104-110).

Long, S. T., \& Freese, J. (2006). Regression model for categorical dependent variables using data. Texas: A Stata Press Publication, College Station.

Lugandu, S. (2013). Factors influencing the adoption of conservation agriculture by smallholder farmers in Karatu and Kongwe districts of Tanzania. Paper presented at REPOA's 18th Annual Research Workshop. Retrieved from http://www.repoa.or.tz/documents_storage/GD8.pdf

Mavunganidze, Z., Madakadze, C. I., Mutenje, J. M., \& Nyamangara, J. (2013). Factors affecting the choice of conservation practices adopted by smallholder cotton farmers in Zimbabwe. African Journal of Agricultural Research, 8(17), 1641-1649. https://doi.org/10.5897/AJAR12.2099

Mazvimavi, K., Ndlovu, P. V., Nyathi, P., \& Minde, I. (2010). Conservation Agriculture Practices and Adoption by Smallholder farmers in Zimbabwe. Paper presented at the $3^{\text {rd }}$ AAAE and 48th AEASA Conference, Cape Town, South Africa, September, 19-23. Retrieved from http://www.foodgrainsbank.ca/uploads/Mazvima vi\%0et\%20al\%202010.pdf

MEA (Millennium Ecosystem Assessment). (2005). Ecosystems and Human Well-being: Synthesis. Island Press, Washington, DC. Retrieved from http://www.millenniumassessment.org/documents/document.356.aspx.pdf

Mlenga, D. H., \& Maseko, S. (2015). Factors influencing adoption of conservation agriculture: A case of increasing resilience to climate variability in Swaziland. Journal of Environment and Earth Science, 5(22). Retrieved from http://www.iiste.org/Journals/index.php/JEES/article/viewFile/27587/28302

Mupangwa, W., Hierfelder, C., \& Mutenje, M. (2012). Increasing Conservation Agriculture Options for Smallholder Farmers in Different Agro-Ecological Areas of Zambia.

Ng'ombe, J., Kalinda, T., Tembo, G., \& Kuntashula, E. (2014). Econometric analysis of the factors that affect adoption of conservation farming practices by smallholder farmers in Zambia. Journal of Sustainable Development, 7(4). https://doi.org/10.5539/jsd.v7n4p124

Ngoma, H., Mapemba, L. D., Tembo, G., \& Maonga, B. (2012). Climate change adaptation strategies by smallhoder farmers in Eastern and Southern Zambia. Msc thesis, University of Malawi, Bunda College of Agriculture.

Nhemachena, C. (2009). Climate Change Dynamics in Africa: Impact and Adaptation Options. Pretoria. University of Pretoria, SA.

Nhemachena, C., \& Hassan, R. (2008). Determinants of African farmers' strategies for adapting to climate change: Multinomial choice analysis. African Journal of Agriculture Resource and Environment, 2(1), 83-104.

Nkala, P. (2012). Assessment of conservation agriculture on farmers' livelihoods in three selected communities in central Mozambique. Doctoral thesis submitted to the University of Natural Resources \& Life Sciences, Vienna, Austria. Retrieved from http://ir.nust.ac.zw/xmlui/handle/123456789/177

Nkala, P., Meyo, N., \& Zikhali, P. (2011). Conservation agriculture and livelihoods of smallholder farmers. Journal of Sustainable Agriculture, 35(7). https://doi.org/10.1080/10440046.2011.606492

Nowak, P. J., \& Korsching, P. J. (1983). Social and Institutional factors affecting the adoption and maintenance of agricultural BMPs. In F. Schaller \& H. Bauley (Eds.), Agricultural Management and Water Quality (1st ed., pp. 349-373). Ames, Iowa, Iowa University Press.

Nyanga, P. H. (2012). Factors influencing adoption and area under conservation agriculture: A case mixed method approach. Sustainable Agriculture Research, 1(2), 27. https://doi.org/10.5539/sar.v1n2p27 
Nyanga, P. H., Johnsen, F. H., Aune, J. B., \& Kalinda, T. H. (2011). Smallholder farmers' perception of climate change and conservation agriculture: Evidence from Zambia. Journal of Sustainable Development, 4(4), 73-84. https://doi.org/10.5539/jsd.v4n4p73

Palliote, J., Smit, B., \& Westerholf, L. (2009). Adaptation and Development: Livelihoods and Climate Change in Subarnabad, Bangladesh.

Pannell, D. J., Llewellyn, R. S., \& Corbeels, M. (2014). Farm level economics of conservation agriculture for resource-poor farmers. Agriculture, Ecosystems and Environment (in press). https://doi.org/10.1016/ j.agee.2013.10.014

Rahn, M. R., \& Huffman, W. E. (1984). The adoption of reduced tillage: The role of human capital and other variables. American Journal of Agricultural Economics, 66, 405-413. https://doi.org/10.2307/1240918

Tadesse, M., \& Belay, K. (2004). Factors influencing adoption of soil conservation measures in Southern Ethiopia: The case of Gununo area. Journal of Agriculture and Rural Development in the Tropics and Sub-Tropics, 105(1). Retrieved from http://www.jarts.info/index.php/jarts/article/view/50/44

Tsegaye, W., Dejenene, A., Rovere, R. L., Mwangi, W., Kassie, T. G., \& Mwabu, G. (2000). Adoption of Conservation Agriculture and its Impact on Land and Labour Productivity in Central Ethiopia. Retrieved from http://libcatalog.cimmyt.org/download/cis/94649.pdf

Twomlow, S., Rohrbach, D., Dimes, J., Rusike, J., Mupangwa, W., Ncube, B., Mahposa, P. (2011). Micro-dosing as a pathway to Africa's green revolution: Evidence from broad scale on-farm trials, in innovations as key to green revolution in Africa (pp. 1101-1113). Springer, Netherlands. Retrieved from http://bob-mccown.com/wp-content/uploads/2011/10/Twomlow2008Microdosing.pdf

Umar, B. B., \& Nyanga, P. (2012). Conservation agriculture and rainfall variability in Zambia: Is CA a promising option for responding to droughts and floods. Department of International Environment and Development Studies, Norwegian University, Norway. Retrieved from http://aciar.gov.au/files/node/13994/ ca_zambia_umar_pdf_24091.pdf

Umar, B. B., Aune, J. B., Johnsen, F. H., \& Lungu, O. I. (2010). Options for improving smallholder conservation agriculture in Zambia. Journal of Agricultural Science, 3(3). https://doi.org/10.5539/ jas.v3n3p50

Wall, P. (2007). Tailoring conservation agriculture to needs of small-scale farmers in developing countries: An analysis of issues. Journal of Crop Improvement, 19(1/2), 137-158. https://doi.org/10.1300/J411v19n 01_07

\section{Copyrights}

Copyright for this article is retained by the author(s), with first publication rights granted to the journal.

This is an open-access article distributed under the terms and conditions of the Creative Commons Attribution license (http://creativecommons.org/licenses/by/4.0/). 